\title{
The Role of Work Culture in Mediating the Effect between Organizational Justice and Pay Satisfaction on Organizational Commitment
}

\author{
Saemu Alwi ${ }^{1}$, Murdjani Kamaluddin ${ }^{2}$, Samdin $^{3}$ \\ ${ }^{1}$ Doctoral Program of Management Science, Halu Oleo University, Kendari, Indonesia \\ ${ }^{2,3}$ Department of Management, Faculty of Business and Economic, Halu Oleo University, Kendari, Indonesia
}

\begin{abstract}
The purpose of this study was to explore the influence of organizational justice, Pay satisfaction and Work culture on organizational commitment. In addition, this study aims to examine and explain the role of work culture in mediating influence between organizational justice and Pay satisfaction on organizational commitment. Design of this study was explanatory; with data collection used survey methods. The amount of sample is determined using a Slovin formula with proportional stratified random sampling technique. The number of respondents of this study was 100 employees. Methods of data analysis used Generalized Structured Component Analysis (GSCA). The results showed that organizational justice and Pay satisfaction has significantly influence on work culture. Organizational Justice and work culture have significant effect on organizational commitment, but Pay satisfaction is not significant effect on organizational commitment. Further, work culture acts as a perfect mediating influence between pay satisfaction and organizational commitment. Finally, the work culture acts as a partial mediation effect between organizational justices with organizational commitment to practical organization. Originality of this study proves the conceptual model that integrates the effect of organizational justice, Pay satisfaction, and organizational culture directly affect organizational commitment, and through the mediating role of work culture.
\end{abstract}

Keywords: Organizational Justice, Pay Satisfaction, Work Culture, Organizational Commitment.

\section{Introduction}

The issue of human resources in the apparatus of government in Indonesia is still in the spotlight. This condition can be observed from the number of responses from the public on the performance of government officials who have demonstrated high capability and unprofessional in their duties lead to low public confidence in the performance of government officials. The fact reflected on the many irregularities that occurred in the bureaucracy that allegedly caused by the lack of commitment of human resources at the government agencies.

Empirical phenomena demonstrate the commitment of the government apparatus can be said is still low because of the quality of human resources in Southeast Sulawesi, which is indicated by the value of the Human Development Index (HDI) is not good for their achievements are ranked 27th nationally with HDI value of 71.73 in 2013. In indicators of life expectancy, has an improvement from 67.40 years in 2008 to 68.56 years in 2013. The average length of school in Southeast Sulawesi increased from 7.74 years in 2008 to 8.44 years in 2013. Meanwhile, the literacy rate indicator, performance in Southeast Sulawesi in 2008 and 2013 increased from 91.42 into 92.59 percent, lower than the national average of 94.14 percent. When viewed from the structure of the labor force by highest level of education attained, the proportion of the labor force with at least high school diploma increased from 32.53 percent in 2008 to 41.35 percent in 2014 (BPS 2015).

Based on the interview with one of the leaders that the future faced with a problem, (1) the work culture is highly bureaucratic state apparatus will be a bottleneck in improving the performance and potential of the resources of the government apparatus. The conditions are the low of employee motivation, a buildup of potential educational background and skills are diverse. (2) The existence of a crisis of leadership that is not able to synergize between organizational justice, pay satisfaction and work culture through integrated model. (3) The equitable treatment within an organization and Pay satisfaction. (4) Improved the quality of government personnel resources. This condition is a problem faced at SKPD in 12 districts/cities and Southeast Sulawesi Province. Because it takes the solution of which are the creation of organizational justice, pay satisfaction, work culture and commitment, that the entire human resource of SKPD Southeast Sulawesi, who are able to contribute to the problems being faced regarding the resources of the government apparatus.

The pattern of development of Human Resources (HR) government officials who previously nationally integrated turn toward coaching separately with the return of the rights of the implementation of regional autonomy. That pattern in turn has implications for the HRM strategy changes, organizational justice, pay satisfaction, and organizational culture on employee commitment between the central government and local governments. Many factors affect the organization's increasing commitment from both technical and behavioral aspects. Dressler (2004), describes the HRM is the process of acquiring, train, assess, and provide compensation to employees, pay attention to their employment, health, and safety, as well as a matter of justice. Consistent with the opinion of Malthis and Jackson (2001) that HRM relates to the formal design of the system to 


\section{International Journal of Science and Research (IJSR) \\ ISSN (Online): 2319-7064 \\ Index Copernicus Value (2013): 6.14 | Impact Factor (2014): 5.611}

determine the effectiveness and efficiency of talent seen someone for realizing the goals of an organization. Referring to the research HRM theory that supported by the theoretical behavior as complementary theory.

Based on behavioral theory developed by Triandis (1971) and Robbins (2003), states that behavior determined by attitude, social rules and customs. Work behavior concerning the activities of individuals in the organization to achieve organizational goals. Increased organizational commitment can be assess from the perspective of universal and contingencies which are influenced by various factors, among others: First, justice organization through equity theory based on social exchange theory by Adam (1965), Tyler (1994), Luthans (2006), Colquitt \& Wesson (2009), and Gibson et al. (2012). Second, pay satisfaction with the theory of pay satisfaction by (Heneman and Schwab (1985), which was developed by Scarpello et al. (1988), Lum et al. (1998); and Yuyetta (2002). Third, work culture (Organizational Culture Theory) by Hofstede (1988); Dressler (2004), Luthans (2006) and Armstrong (2003). Fourth, organizational commitment (Robbins, 2003; Armstrong, 2003 and Dressler, 2004).

Results of previous studies have shown that organizational justice, pay satisfaction and good work culture can improve organizational commitment. Although empirically turned out to research the influence of these variables are very diverse and contradictory. Therefore, researchers interested in conducting re-examination of the influence of these variables integrated manner. First, the study was conducted by Abubakar and Majid 2013), Ahmad Sani (2013), Mehmet et al. (2014), Harris (2015), and Taner Bahar et al. (2015) found that organizational justice positive and significant effect on organizational commitment. Secondly, the research that has proven that high Pay satisfaction contribute significantly and may increase organizational commitment by Rita Andini (2006), Jonathan and Luke Singer (2014), A'yuninnisa and Saptoto (2015). Third, the organizational culture positive has significant effect on organizational commitment by Wolfgang (2013), and Huma Abid et al. (2014).

The findings of previous studies are research gap by Chess and Pearl (2015) and Mohamed Ibrahim \& Ann Perez (2014) found that organizational justice not significant effect on organizational commitment. The argument can perceived researchers caused by the diversity of indicator variables in measurement, the object studied, methods, and basic theory used to further research into the gap to perform testing of the contradiction becomes important. Thus the test results of previous investigators, there is still a contradiction that is an avenue to test back against the influence of organizational justice, pay satisfaction and workplace culture on organizational commitment.

The main problem is whether justice research organization, Pay satisfaction and work culture influence the organizational commitment either directly, or through a mediating role in the work culture sectors in 12 districts / cities and Southeast Sulawesi Province. The aim is to examine and explain the influence of organizational justice, pay satisfaction, and culture on organizational commitment either directly, or through the mediation of the work culture. The results of this study expected to contribute to the development of theory for equity in particular academic theory, performance theory, organizational culture theory, and the theory of contingency, general human resource management and organizational behavior. Besides contributing as input for management to employees on education in 12 districts/cities Southeast Sulawesi province, in particular the management of employees in formulating strategies, policies and programs to improve HRM strategy, organizational justice, pay satisfaction, culture and organizational commitment.

\section{Research Methods}

The study design is intended to provide an explanation for the influence of organizational justice, pay satisfaction, and cultural, organizational commitment towards either directly (universal) or contingency in SKPD employees in 12 regencies/cities and Southeast Sulawesi Province. This research approach uses a positivist paradigm with the kind of explanatory Research, where data collection through a survey method. Explanatory research is intended to provide an explanation for the development of agro-industrial model of cocoa or aim to obtain a proper test in drawing conclusions that are causality (Cooper \& Schindler, 2003).

The study population was all employees on education in 12 districts/cities and Southeast Sulawesi provincial administration with the number of employees 79299 people. The determination of the sample of employees from each SKPD chosen with the sampling technique used is random based strata (stratified proportional random sampling), the first classifying the population into sub-populations of employees on education in 12 districts/ cities and local governments Sulawesi Province Southeast. The sample size in this study quantified using the formula Slovin quoted Uma Sekaran (2003), as follows:

$$
\mathrm{n}=\frac{\mathrm{N}}{1+\mathrm{N}(\mathrm{e})^{2}}=\frac{79.299}{1+79.299(0.01)^{2}}=99.87 \text { or } 100 \text { people. }
$$

Methods of data collection conducted by survey that distributing questionnaires to employees. Questionnaire conducted by visiting officials and explained the questionnaire and waiting when the questionnaire can take. Finally, researchers conducted in-depth interviews; these techniques used to support and reveal the facts behind the findings of the quantitative analysis. Furthermore, a scale of measurement data from all study variables used Likert scale. A five-point Likert scale was employed with a score of 1, Indicating "strongly disagree" and 5 representing "strongly agree" to extract the different attitudes of respondents Cooper \& Sehindler (2003).

Data analysis method used is the Generalized Structured Component Analysis (GSCA). GSCA developed by Heungsun \& Takane (2004) aims at replacing factors with a linear combination of variables manifest in the SEM. Heungsun (2009) says GSCA is a method of SEM-based components, is very important and can be used for calculation of score (not to scale) and can also be applied to a 


\section{International Journal of Science and Research (IJSR) \\ ISSN (Online): 2319-7064 \\ Index Copernicus Value (2013): 6.14 | Impact Factor (2014): 5.611}

small sample. Multikolinearitas singularity problem and often a serious obstacle in the analysis of the structural model using covariance-based SEM. Hwang et al. (2010) stated GSCA allow the multikolinearitas, which a strong correlation between the exogenous variables. Besides, GSCA can use in the structural model both reflective and formative.

SEM analysis based components GSCA is an alternative method of analysis that is better than AMOS and PLS, which has a better recovery parameter Hwang, et al. (2010). However, GSCA can also be applied to the structural model already strong theoretical foundation, or in other words as a confirmatory method of analysis. GSCA is a powerful analytical method because it can apply at all scales. Moreover, it does not require many assumptions and the sample size should not be large. GSCA prediction model is the least squares estimation methods. In GSCA structural models and measurement models are integrated into one model, so that the parameter estimation process oriented in alternating least squares Heungsun (2009). Parameter estimation GSCA includes three categories, namely: (1) weight and loading estimate, (2) path estimate, and (3) mean weight, loading and path coefficient. In the analysis of GSCA measure of fit (goodness of fit) can be done on the measurement model, and overall structural models even combined measurement model and structural model in particular indicators that are reflective.

\section{Analysis and Results}

Southeast Sulawesi economic growth predicted to reach 7.3\% in 2016. This growth was higher than in 2016, which until recently listed the third quarter to $6.3 \%$. The most reliable sectors namely agriculture and mining. Chief Representative Monetary Economics BI Southeast Sulawesi, said prioritizing in the agricultural sector is very promising because it will be the rainy season. Government should focus on the development of agricultural programs. Can through the addition of land, guarantees the availability of seeds and fertilizers as well as an increase in irrigation.

The respondents are the Civil Servants at SKPD in Southeast Sulawesi provincial government, which amounted to 100 people. Profile of respondents to describe the characteristics of Civil Servants explain the characteristics of the sampled according to gender, age, education, past employment and marital status.

Table 1: Respondents Profile

\begin{tabular}{llc}
\hline \multicolumn{2}{c}{ Responde nts profile } & Percent \\
\hline 1. Sex & Man & 57 \\
& Woman & 43 \\
2. Age (years) & $24-30$ & 13 \\
& $31-40$ & 45 \\
& $41-50$ & 28 \\
3. Working duration & $51-59$ & 14 \\
(years) & $2-9$ & 36 \\
& $10-19$ & 43 \\
& $20-25$ & 10 \\
4. Education Leve1 & $26-31$ & 11 \\
& Bachelor & 81 \\
& Magister & 18 \\
& Doctoral & 1 \\
\hline
\end{tabular}

Notes: $\mathrm{n}=100$
Results of the assessment of respondents to the indicator variable measurement are reflected through the mean value aims to determine the actual condition of each indicator that respondents perceived. Then the loading factor aims to find the strongest measuring variables against each indicator in reflecting any latent variables can be seen in Table 2 .

Table 2: Mean, Factor Loading, AVE and Alpha

\begin{tabular}{|c|c|c|c|c|c|c|}
\hline \multirow{2}{*}{ Constructs/Indicators } & \multirow[b]{2}{*}{ Mean } & \multicolumn{3}{|c|}{ Factor loading } & \multirow[b]{2}{*}{$A V E$} & \multirow[b]{2}{*}{ Apha } \\
\hline & & Estimate & SE & $\mathrm{CR}$ & & \\
\hline Organizational Justice (OJ): & 4.16 & & & & 0.703 & 0.853 \\
\hline OJ1. Distributive justice & 4.13 & 0.866 & 0.030 & $28.77^{*}$ & & \\
\hline OJ2. Procedural justice & 4.10 & 0.779 & 0.039 & $19.82^{*}$ & & \\
\hline OJ3. Interpersonal justice & 4.23 & 0.854 & 0.028 & $30.16^{*}$ & & \\
\hline OJ4. Informational justice & 4.20 & 0.852 & 0.038 & $22.56^{*}$ & & \\
\hline Pay Satisfaction (PS): & 4.03 & & & & 0.616 & 0.661 \\
\hline PS1. Pay level & 4.30 & 0.784 & 0.051 & $15.4^{*}$ & & \\
\hline PS2. Pay benefits & 4.34 & 0.821 & 0.027 & $30.27^{*}$ & & \\
\hline PS3. Pay raise & 3.54 & 0.602 & 0.104 & $5.79^{*}$ & & \\
\hline PS4. Pay structure \& administration & 3.93 & 0.643 & 0.088 & $7.31^{*}$ & & \\
\hline Work culture (WC): & 3.98 & & & & 0.634 & 0.769 \\
\hline WC1. innovation and risk taking & 3.87 & 0.671 & 0.079 & $8.45^{*}$. & & \\
\hline WC2. details of the task & 3.90 & 0.66 & 0.062 & $10.72^{\circ}$. & & \\
\hline WC3. results orientation & 4.17 & 0.754 & 0.05 & $14.99^{*}$ & & \\
\hline WC4. personal orientation & 4.00 & 0.635 & 0.059 & $10.71^{*}$ & & \\
\hline WC5. team orientation & 3.76 & 0.602 & 0.076 & $7.92^{*}$ & & \\
\hline WC6. aggressiveness & 4.12 & 0.715 & 0.046 & $15.44^{*}$ & & \\
\hline WC7. Stability & 4.06 & 0.55 & 0.112 & $4.92^{\circ}$ & & \\
\hline Organizational Commitment $(O C)$ : & 4.19 & & & & 0.692 & 0.777 \\
\hline OC1. A fektif commitment & 4.14 & 0.765 & 0.052 & $14.61^{*}$ & & \\
\hline $\mathrm{OC} 2$. Continuence commitment & 4.18 & 0.868 & 0.039 & $22.1^{\circ}$ & & \\
\hline OC3. Normatif commitment & 4.24 & 0.86 & 0.029 & $29.34^{*}$ & & \\
\hline
\end{tabular}

Notes: * significant at .05 level; AVE > .50 and Alpha > .70

AVE value in Table 2 shows the whole construct has good discriminant validity. So that the instrument used in this study deserve to be used as a measure because they meet the criteria of discriminant validity. Furthermore, the value of alpha $\geq 0.70$ that is to say all variables tested had good composite reliability. It can conclude research instrument is feasible to use for the measurement of all variables of this study because it has high compatibility and reliability. These results can also prove by the value correlations of latent variables (SE) Table 3.

Table 3: Correlations of Latent Variables (SE)

\begin{tabular}{|c|c|c|c|c|}
\hline \multicolumn{5}{|c|}{ Correlations of Latent Variables (SE) } \\
\hline & OJ & PS & WC & OC \\
\hline OJ & 1 & $0.495(0.096)^{*}$ & $0.491(0.074)^{*}$ & $0.502(0.082)^{*}$ \\
\hline PS & $0.495(0.096)^{*}$ & 1 & $0.666(0.054)^{*}$ & $0.542(0.087)^{*}$ \\
\hline WC & $0.491(0.074)^{*}$ & $0.666(0.054)^{*}$ & 1 & $0.648(0.061)^{*}$ \\
\hline OC & $0.502(0.082)^{*}$ & $0.542(0.087)$ & $0.648(0.061)^{*}$ & 1 \\
\hline Notes: OJ = Organizational Justice; PS = Pay Satisfaction; WC $=$ \\
Work Culture; OC = Organizational Commitment. \\
\hline
\end{tabular}

The model we tested said to be fit when they supported by empirical data. GSCA provides a measure of goodness-of-fit which consists of structural models and the overall fit models that can be seen from the FIT, AFIT, GFI (Unweighted leastsquares) and SRMR (Standardized root mean square residual). Output GSCA in Figure 2 is known AFIT value = 0489 means that the diversity of organizational variables justice, pay satisfaction, work culture, and organizational commitment can be explained in the model and the remaining $48.60 \%$. The results of data analysis known value $\geq 0.90$ GFI $=0983$ then the models created can be said is good. However SRMR value $=0.137>0.1$ can be said poor fit. This result 


\section{International Journal of Science and Research (IJSR) \\ ISSN (Online): 2319-7064 \\ Index Copernicus Value (2013): 6.14 | Impact Factor (2014): 5.611}

was possible because the direction indicator measurement between variables is not known with certainty and the influence of the complexity of the model, but can be tolerated because SRMR values close to zero (Ghazali, 2008). Furthermore, the structural model is evaluated by looking at the path coefficient value of the relationship between the latent variables. The test results are presented in the path diagram Figure 2.

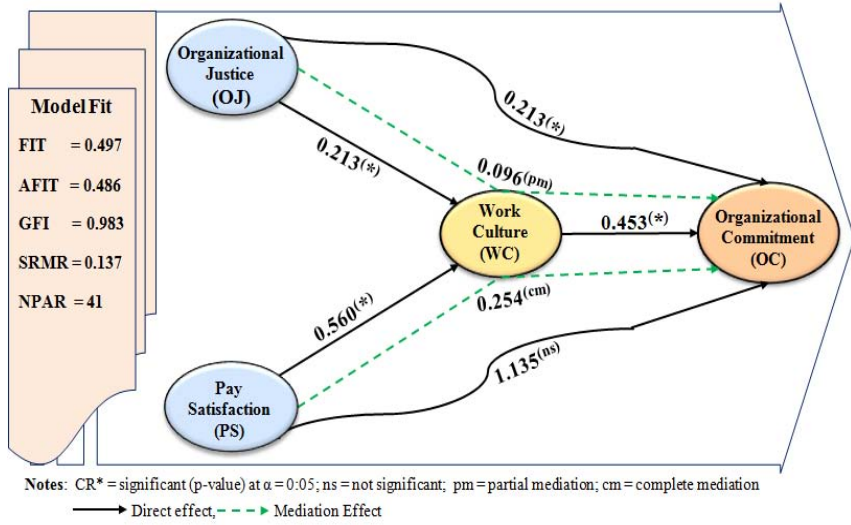

Figure 2: Hypothesis Testing and Path Coefficient

Table 4: Structural Model GSCA

\begin{tabular}{|c|c|c|c|c|c|c|}
\hline \multirow{2}{*}{$\begin{array}{l}\text { Hypothesis } \\
\text { Testing }\end{array}$} & \multicolumn{4}{|c|}{ Path Coefficients } & \multirow{2}{*}{\multicolumn{2}{|c|}{ Empirical Evidence }} \\
\hline & Estimate & $\mathrm{SE}$ & $\mathrm{CR}$ & p-value & & \\
\hline $\mathrm{H}_{\mathrm{la}} \quad \mathrm{OJ}->\mathrm{WC}$ & 0.213 & 0.067 & $3.17^{*}$ & 0.002 & Significant & Accepted \\
\hline PS->WC & 0.560 & 0.062 & $9.11^{\circ}$ & 0.000 & Significant & Accepted \\
\hline $\mathrm{OJ}-\mathrm{OC}$ & 0.213 & 0.100 & $2.12^{*}$ & 0.037 & Significant & Accepted \\
\hline $\mathrm{PS} \rightarrow>\mathrm{OC}$ & 0.135 & 0.133 & 1.01 & 0.315 & Not-Significant & Rejected \\
\hline $\mathrm{H}_{2 c} \quad \mathrm{WC}>\mathrm{OC}$ & 0.453 & 0.127 & $3.58^{\circ}$ & 0.001 & Significant & Accepted \\
\hline \multicolumn{7}{|c|}{ Pengaruh Variabe1 Mediasi } \\
\hline Eksogen & Mediasi $\quad \mathrm{B}$ & Endogen & \multicolumn{2}{|c|}{ Coefficients } & \multicolumn{2}{|c|}{ Results } \\
\hline $\mathrm{H}_{3 \mathrm{a}} \quad \mathrm{OJ} \rightarrow$ & WC--> & $\mathrm{OC}$ & & .096 & $\begin{array}{c}\text { Partial } \\
\text { Mediation }\end{array}$ & Accepted \\
\hline $\mathrm{H}_{3 \mathrm{~b} .} \quad$ PS $->$ & WC--> & $\mathrm{OC}$ & & 254 & $\begin{array}{l}\text { Complete } \\
\text { Mediation }\end{array}$ & Accepted \\
\hline
\end{tabular}

Notes: OJ = Organizational Justice; PS = Pay Satisfaction; WC = Work Culture; $\mathrm{OC}=$ Organizationa 1 Commitment and $\mathrm{CR}^{*}=$ significant at .05 level

The test results in Figure 2 and Table 4 proves that organizational justice and pay satisfaction positive and significant impact on the work culture ( $\mathrm{H} 1 \mathrm{a}$ and $\mathrm{H} 1 \mathrm{~b}$, accepted). The test results of organizational justice and workplace culture positive and significant effect on organizational commitment. These findings may prove (H2a \& H2C, accepted), means the better implementation of organizational justice and work culture can make a significant contribution to the improvement of organizational commitment. Value estimate the path coefficient of pay satisfaction on organizational commitment $=0.135$ with CR $=1: 01$ and $p$-value $=0.315>\alpha=0: 05$. The test results cannot prove (H2b, Rejected) expressed satisfaction that pay significant effect on organizational commitment.

The evaluation results of testing the effect of organizational justice variables on organizational commitment at an early model with variables mediating role involves working culture, show justice organization directly significantly influence the work culture and organizational commitment. Then the variable work culture is also a significant effect on organizational commitment, so that the nature of the mediating effect of organizational justice on organizational commitment through the role of workplace culture is a partial mediation. There is enough evidence to accept (H3a) that high work culture can act as a mediating influence between organizational justice and organizational commitment. That is justice organization can directly affect the organizational commitment can also be through the role of workplace culture.

Testing the effect of Pay satisfaction on organizational commitment mediating by work culture, Pay satisfaction has not significant effect on organizational commitment. However, pay satisfaction has significantly influence the culture of the organization. Then the work culture has significantly influence organizational commitment. Thus, the role of corporate culture in the model is a complete mediation. This means that the Pay satisfaction not significant effect on commitment. Furthermore, through mediation role workplace culture can significantly affect organizational commitment. Thus, there is sufficient evidence to accept (H4b) that culture can play a high work perfectly in mediating the effects of pay satisfaction and organizational commitment. It can be concluded that the application of a good Pay satisfaction not significant effect on organizational commitment, but with the mediation role of the working culture significantly influence organizational commitment.

\section{Discussion}

The test results found that organizational justice and Pay satisfaction positive and significant impact on the culture of the organization. The results of the study indicate that the better implementation of organizational justice and Pay satisfaction, the higher the culture of the organization. The findings of this study can explain that the implementation of organizational justice and Pay satisfaction is able to support changes in the variation of the increase in work culture. Referring to the findings of the study that organizational justice and the satisfaction of a good Pay is able to improve the work culture. This result validating the theory of organizational justice through equity theory based on social exchange theory by Adam (1965), Tyler (1994), Luthans (2006), Colquitt \& Wesson (2009), and Gibson et al. (2012). Then to prove the theory of pay satisfaction by (Heneman and Schwab (1985), which was developed by Scarpello et al. (1988), and Yuyetta (2002)). Ultimately prove organizational culture theory by Hofstede (1988); Robbins (2003), Dressler (2004) and Armstrong (2003).

The study's findings support the results of the study One Diab (2015), found that organizational justice positive and significant impact on the work culture. The study's findings are also consistent with the results of research conducted by Padliansyah et al. (2015), Ashish and Philip Benson (2013), and Xinyan Wang et al. (2010) that organizational justice positive and significant impact on the work culture. The results of this study reinforce research findings Ilham Thaief, et al. (2015), and Idrees Zahra et al. (2015) that pay satisfaction positive and significant impact on the work culture. There is a gap or difference of research findings by Christian and Tremblay (2008), and Abdul Hameed, et al. 


\section{International Journal of Science and Research (IJSR) ISSN (Online): 2319-7064 \\ Index Copernicus Value (2013): 6.14 | Impact Factor (2014): 5.611}

(2013) found that the pay satisfaction and no significant negative impact on the work culture.

The findings of this study organizational justice and Pay satisfaction has positive and significant impact on organizational commitment, but the work culture not significant effect on organizational commitment. Referring to the findings of the study that implementation of organizational justice, pay satisfaction and organizational culture are well able to increase employee commitment. Organization can prove the truth of a theory of justice based on the theory of social exchange in which individuals expect that they will get an exchange efforts and rewards equitably from the organization (Tyler, 1994). Furthermore, the theory of organizational commitment is a state employee favoring certain organization, goals and desires to retain membership in the organization (Allen and Meyer, 1990; Robbins and Judges, 2007).

Organizational justice theory originally derived from the similarity theory developed by Adams (1965) that the sense of injustice would occur if the ratio between the results achieved with the input somebody he gave for an exchange considered disproportionate when compared with other referent. Implementation of organizational justice required a deep commitment to the organization that is part of the HRM (Armstrong (2003). Furthermore, Armstrong (2003) suggests that there is a strong relationship between the implementation of organizational justice and organizational commitment to employee performance. One important key to getting commitment is to help them actualize themselves to achieve the goal (Dressler, 2004).

The results of this study prove the truth of the theory of organizational commitment of Allen and Meyer (1990), Robbins (2003), Armstrong (2003) and Dressler (2004) that the employees who have committed high organizational dedicatedly, where employees have a desire to provide power and responsibility to support the welfare and success of the organization. Furthermore, the results of this study found that organizational justice has positive and significant effect on organizational commitment. This result support the research findings Mustafa Yavuz (2010), Abubakar Suliman and Majid Al Kathairi (2013), Ahmad Sani (2013), Mehmet Fatih et al. (2014), Norhani Bakri \& Nazim Ali (2015), and Taner Bahar et al. (2015). Instead contrast to the US Chess research findings and the Pearl (2015) and Mohamed Ibrahim \& Ann Perez (2014) found that organizational justice not significant effect on organizational commitment.

The findings of this study indicate Pay satisfaction has positive and significant influence impact on organizational commitment. This fact can prove that the higher the Pay satisfaction on employee commitment to the organization increases. The findings of this study reflect that improving satisfaction of employee salaries in sectors in 12 districts / cities and Southeast Sulawesi province is able to support changes in the variation increase organizational commitment. Referring to the findings of research that satisfaction with the Pay received by an employee equity based on a theory developed by Adam 1963 quoted Gibson (2000) that the employee or the individual will feel the satisfaction in the work of the special aspects of its work; special aspect is for example reward / Pay, coworkers, and supervisor. Individuals feel any sense of fairness (equity) of the Pay received in connection with the work he did (Lum et al., 1998).

The results of this study prove the truth of the theory of pay satisfaction. Expressed Heneman and Schwab (1985), which was developed by Lum et al. (1998); and Yuyetta (2002) can be concluded that satisfaction and dissatisfaction over the Pay received is a function of a mismatch between what is perceived to be accepted by someone with how much a person receives. The results of this study supports and are consistent with the findings of the study Rita Andini (2006), A'yuninnisa and Saptoto (2015) that the satisfactions of Pay high contribute significantly and may increase organizational commitment.

The results of this research note organizational culture not significant effect on organizational commitment. This means that the implementation of an organizational culture that both unidirectional and not significant effect on improvement of organizational commitment. Thus the results of this study cannot prove that the better the culture of the organization, the higher organizational commitment. The findings of this study reflect that organizational culture is good at SKPD in 12 districts / cities and Southeast Sulawesi province is able to support changes in the variation increase organizational commitment. The findings of this study cannot prove the theory of attitudes and organizational behavior developed by Triandis (1971) that the behavior determined by attitude, social rules and customs. Work behavior concerning the activities of individuals in the organization in achieving organizational goals. Furthermore, the results of this study cannot prove a theory put forward culture Hofstede (1994), Davis et al. (1997), Robbins (2003) and Luthans (2003). The results of this study cannot strengthen the research Antonio Ortega et al. (2013), and Huma Abid et al. (2014) that organizational culture positive and significant effect on organizational commitment.

The findings of this study can prove that the work culture can act as a perfect mediating influence between pay satisfaction and organizational commitment. Further, on organizational justice organizational commitment, work culture acts as a partial mediation. These results prove the theory of HRM and organizational behavior that the capability of human resources is a potential resource for sustainability for the organization that includes three perspectives: universal, contingency and configuration by Thompson, 1967 and Donaldson, 2001. The results of this study confirmation argument is built on the existence "best practices" in approach to HRM by Xinyan Wang et al. (2010), Abubakar Suliman and Majid Al Kathairi (2013), Kris Harris (2015). The study's findings reinforce the view from the perspective of contingency and configuration Xinyan et al. (2010) and Isabel et al. (2015).

\section{Conclusion}

Improved organizational justice and pay satisfaction has contributed significantly to the organization's culture. The 


\section{International Journal of Science and Research (IJSR) \\ ISSN (Online): 2319-7064}

Index Copernicus Value (2013): 6.14 | Impact Factor (2014): 5.611

findings of this study can be interpreted that the dominant organizational justice is reflected by distributive justice and satisfaction with Pay received benefits have contributed significantly to the increase in the aggressiveness which is a reflection of the work culture. Further organizational justice, Pay satisfaction and organizational culture that high has contributed significantly to the improvement of organizational commitment. The findings of this study can interpreted that the improvement of organizational justice is more dominant reflected by indicators of distributive justice, satisfaction with the Pay and benefits of aggressiveness indicators are a reflection of organizational culture has contributed significantly to the improvement of organizational commitment.

Work culture acts as a mediating influence perfect on pay satisfaction and organizational commitment. Then justice organizations on organizational commitment, work culture acts as a partial mediation. This means that an increase in pay satisfaction cannot contribute significantly to organizational commitment, but with mediation work culture are perfectly able to make a significant contribution to organizational commitment. Furthermore, justice organization has contributed significantly to the improvement of organizational commitment, as well as through the mediating role of work culture can significantly increase the commitment of the organization.

\section{References}

[1] A'yuninnisa, Rizqi dan Saptoto, Ridwan (2015) The effects of pay satisfaction and affective commitment on turnover intention. International Journal of Research Studies in Psychology 2015 April, Volume 4 Number 2, 57-70

[2] Abdul Hameed, Mphil, Muhammad Ramzan, Hafiz M. Kashif Zubair, Ghazanfar Ali, Muhammad Arslan (2013) Impact of Compensation on Employee Performance (Empirical Evidence from Banking Sector of Pakistan). International Journal of Business and Social Science Vol. 5 No. 2; February 2014, pp 302309

[3] Abubakar Suliman and Majid Al Kathairi (2013) Organizational justice, commitment and performance in developing countries The case of the UAE. Employee Relations Vol. 35 No. 1, 2013 pp. 98-115.

[4] Achmad Sani (2013) Role of Procedural Justice, Organizational Commitment and Job Satisfaction on job Performance: The Mediating Effects of Organizational Citizenship Behavior. International Journal of Business and Management; Vol. 8, No. 15; pp 57-67

[5] Amstrong, Michael, (2003) Strategic HRM, A Guide to Action. Kogan Page Ltd 120 Pentonville Road, London. Alih Bahasa Ati Cahayati. PT Buana Ilmu Populer. Jakarta.

[6] Antonio Ortega; Parra Miguel Ángel Sastre and Castillo, (2013), Impact of perceived corporate culture on organizational commitment, Management Decision, Vol. 51 Iss 5 pp. 1071 - 1083
[7] Central Statistics Agency [BPS]. (2015) Southeast Sulawesi in figures 2011. Statistic Southeast Sulawesi Province, Kendari

[8] Cevahir Uzkurt, Rachna Kumar and Halil Semih Kimzan (2013), Role of innovation in the relationship between organizational culture and firm performance A study of the banking sector in Turkey. European Journal of Innovation Management Vol. 16 No. 1, 2013 pp. 92-117.

[9] Chaterina Melina Taurisa dan Intan Ratnawati (2012) Analysis of Effect of Organizational Culture and Organizational Commitment on Job Satisfaction in Improving The Performance of Employees (Study on PT. Sido Muncul Kaligawe Semarang). Jurnal Bisnis dan Ekonomi (JBE), Vol. 19, No. 2, Hal. 170 - 187

[10] Christian Vandenberghe and Michel Tremblay (2008) The Role of Pay Satisfaction and Organizational Commitment in Turnover Intentions: A Two-Sample Study. Journal of Business and Psychology Vol. 22(3), pp. 275-286

[11] Colquitt Jason A, Donald E Conlon, Michael J Wesson, Christopher OLH Porter, K Yee Ng (2001). Justice at the millennium: a meta-analytic review of 25 years of organizational justice research. Journal of applied psychology, 86 (3) 425

[12] Colquitt, J. A., LePine, J. A., \& Wesson, M. J. (2009). Organizational behavior: Improving perfor-mance and commitment in the workplace. Uni-ted States: McGrawHill.

[13] Currall, S.C., Towler, A.J., Judge, T.A., \& Kohn, L. (2005). Pay Satisfaction and Organizational Outcomes. Personnel Psychology, 58, 613-640.

[14] Dhaifallah Obaid Almutairi (2016) The Mediating Effects of Organizational Commitment on the Relationship between Transformational Leadership Style and Job Performance. International Journal of Business and Management; Vol. 11, (1). Pp. 231-241.

[15] Dressler, Garry. (2004). Human Resource Management. Edisi 7 Jilid I. Alih Bahasa Benyamin Molan . PT Prenhallindo. Jakarta

[16] Ezekiel Saasongu Nongo \& Darius Ngutor Ikyanyon (2012) The Influence of Corporate Culture on Employee Commitment to the Organization. International Journal of Business and Management; Vol. 7, No. 22, pp 1-8

[17] Faisal Karim, dan Omar Rehman (2012) Impact of Job Satisfaction, Perceived Organizational Justice and Employee Empowerment on Organizational Commitment in Semi-Government Organizations of Pakistan. Journal of Business Studies Quarterly 2012, Vol. 3, No. 4, pp. 92-104

[18] Fateme Nikkhah Amirabad, Nadreh Sohrabi, dan Siamak Samani (2014). Relationship Between Organizational Justice, Work Conscience And Organizational Commitment Of Personnel's Of Gas Company In Yasouj. Kuwait Chapter of Arabian. Journal of Business and Management Review Vol. 3(8), pp. 74-82.

[19] Faulk III, Lary H (2002), Pay satisfaction Consequences: Development and test of a theoritical model Ph.D dissertation of the Graduate Faculty of Lousiana State University

\section{Volume 5 Issue 3, March 2016}




\section{International Journal of Science and Research (IJSR) \\ ISSN (Online): 2319-7064}

Index Copernicus Value (2013): 6.14 | Impact Factor (2014): 5.611

and Agricultural and Mechanical College in the interdepartmental program of Business Administration.

[20] Gibson, J. L., Donnelly, J. H., Ivancevich, J. M., \& Konopaske, R. (2012). Organizations: Behavior, structure, processes. Singapore: McGraw-Hill.

[21] Heneman, H.G. and Schwab, D.P. (1985), Pay satisfaction: its multidimensional nature and measurement, International Journal of Psychology, Vol. 20 No. 2, pp. 129-141.

[22] Hofstede . G, (1994). Cultures and Organizations: Intercultural Cooperation and its Importance for Survival . London : Harper Collins Publisher

[23] Huma Abid Alvi, Mehmood Hanif, Muhammad Shahnawaz Adil, Rizwan Raheem Ahmed, Jolita Vveinhardt (2014) Impact of Organizational Culture on Organizational Commitment and Job Satisfaction. European Journal of Business and Management Vol.6, No.27, 2014.

[24] Kreitner dan Kinicki. (2005). Perilaku Organisasi. Salemba Empat Jakarta

[25] Luthans , Fred. (2006) Perilaku Organisasi, Penerbit Andi, Yogyakarta

[26] Malthis, Robert L. and Jackson, John H. (2001). Human Resouce Management. $9^{\text {th }}$ Edition. Alih Bahasa Jimmy Sadeli Cs. PT Salemba Emban Patria. Jakarta

[27] Masoud Ghorbanhosseini (2013) The Effect of Organizational Culture, Teamwork and Organizational Development on Organizational Commitment: The Mediating Role of Human Capital. Tehnički vjesnik Vol. 20 (6), pp. 1019-1025

[28] Mathis, Robert L. \& Jackson, John H. (2001), Manajemen Sumberdaya Manusia, Buku I, Terjemahan, Jakarta: Salemba Empat

[29] Matthew S. Crow, Chang-Bae Lee dan Jae-Jin Joo (2012) Organizational justice and organizational commitment among South Korean police officers An investigation of job satisfaction as a mediator. Policing: An International Journal of Police Strategies \& Management Vol. 35 No. 2, 2012 pp. 402-423

[30] Mehmet Fatih Yasar, Abdurrahim Emhan dan Pauline Ebere (2014) Analysis of Organizational Justice, Supervisor Support, and Organizational Commitment: A Case Study of Energy Sector in Nigeria. Journal of Business Studies Quarterly, Volume 5, Number 3 pp. 37-46

[31] Mohamed Ibrahim \& Ann Perez (2014), Effects of Organizational Justice, Employee Satisfaction, and Gender on Employees' Commitment: Evidence from the UAE. International Journal of Business and Management; Vol. 9, No. 2, pp 45-59

[32] Muhammad Arifin (2015) The Influence of Competence, Motivation, and Organisational Culture to High School Teacher Job Satisfaction and Performance, International Education Studies; Vol. 8, No. 1; 2015, pp. 38-45

[33] Mustafa Yavuz (2010) The effects of teachers' perception of organizational justice and culture on organizational commitment. African Journal of Business Management Vol. 4(5), pp. 695-701

[34] Rita Andini (2006) Influence Analysis Satisfaction Salary, Job Satisfaction, Organizational Commitment
Against Turnover Intention. Thesis. Graduate Program, Diponegoro University, Semarang.

[35] Robbins, P. Stephen, (2003). Organizational Behavior: Concepts, Controversies and Applications. Interpreting Hadyana Pudjaatmaka. Indonesian edition. Jakarta: Prenhalindo.

[36] Romy Lee (2013) Pay Satisfaction, Organisational Commitment, Voluntary Turnover Intention, and Attitudes to Money in a South African Context. Masters Degree In Organisational Psychology. Faculty of Humanities, University of the Witwatersrand, Johannesburg, 22 March 2013.

[37] Salah Diab (2015) The Impact o f Organizational Justice on the Workers Performance and Job Satisfaction in the Ministry of Health Hospitals in Amman. Published by Canadian Center of Science and Education, International Business Research; Vol. 8, No. 2; pp. 187-197

[38] Schermerhorn, James G. Hunt, Richard N. Osborn, dan Mary Uhl-bien (2010). Organizational Behavior, John Wiley \& Sons: 11th Edition,

[39] Sekaran, Uma. 2003. Research Methods for Business: A Skill Building Approach, Fourth Edition, John Willey \& Sons, Inc. New York.

[40] Sofyan Fadli Anshary Rumasukun, Yohanis Rante, Oscar O. Wambrauw, Bonifasia Elita Bharanti (2015), The Influence of Human Resource Management Strategy and Competence on Employee Performance with the Mediation of Work Motivation, Organizational Commitment and Work Culture. International Journal of Business and Management Invention Vol 4 Issue 8 || August. 2015 || PP-15-27

[41] Tamkeen Saleem and Seema Gu (2013) Drivers of Turnover Intention in Public Sector Organizations: Pay Satisfaction, Organizational Commitment and Employment Opportunities. Middle-East Journal of Scientific Research 17 (6): 697-704

[42] Thompson, J.D., 1967. Organizations in Action. McGraw-Hill, New York, NY.

[43] Triandis, (1971). Attitudes and Attitudes Change. Jhon Waley \& Sons, Inc,New York.

[44] Welbourne (2002). Culture, children's rights and child protection. Article first published online: 31 DEC 2002. DOI: 10.1002/car.772.

[45] Wolfgang Messner, (2013), Effect of organizational culture on employee commitment in the Indian IT services sourcing industry, Journal of Indian Business Research, Vol. 5 Iss 2 pp. 76 - 100

[46] Xinyan Wang, Jianqiao Liao, Degen Xia, Tao Chang (2010) The impact of organizational justice on work performance Mediating effects of organizational commitment and leader-member exchange. International Journal of Manpower Vol. 31 No. 6, 2010 pp. 660-677

[47] Cooper, D. R., \& Schindler, P. S. (2003). Business research methods (8th ed.). New York, NY: McGrawHill/Irwin.

[48] Hwang, H. (2009). Regularized generalized structured component analysis. Psychometrika, 74(1), 517-530.

[49] Hwang, \& Takane, (2004). Generalized structured component analysis. Psychometrika, 69(1), 81-99. 